Metodički obzori 7(2012)1

Original research paper

UDK: 371.311.4:159.95

Received: 23. 11. 2010.

\title{
ERR FRAMEWORK SYSTEM AND COOPERATIVE LEARNING
}

\author{
Fehim Terzić, MSc \\ Education Advisor \\ Pedagogical Institute of Zenica-Doboj Canton \\ (Bosnia and Herzegovina) \\ e-mail: fehimterzic@gmail.com
}

\begin{abstract}
A b stract
The training program "Reading and Writing for Critical Thinking" (RWCT) represents a comprehensive approach and introduction of a new methodology that promotes active, independent learning and critical thinking. RWCT methods include research strategies, creative thinking, cooperative learning, discussion and debate, writing as a tool of personal expression and a teaching aid. In Bosnia and Herzegovina this training is conducted by COI "Step by Step" from Sarajevo, and training is also attended by the teachers from the Zenica-Doboj Canton. The basic training objectives are: developing teachers' competence for the implementation of the ERR framework system and various forms of cooperative learning as contemporary strategies that contribute to the development of students' critical thinking. This paper's objective is to examine whether the attitudes of students in elementary school are positive or negative if we talk about the role and importance of the ERR framework system and cooperative learning in the process of acquiring knowledge. The following methods were used in the study: theoretical analysis, the descriptive-analytical methods and survey method. The instrument comprised a specially designed assessment scale for students (SPU). The study results contribute to the affirmation of modern teaching and learning strategies such as the ERR framework system and cooperative learning because they contribute to the cognitive, conative and affective development of students and strengthen their competences for the $21^{\text {st }}$ century.
\end{abstract}

Key words: ERR framework system, cooperative learning, cooperative groups, critical thinking, evocation, understanding the meaning, reflection, teaching

\section{Introduction}

Each student is an individual person and has his own style of learning. Differentiating instruction and using modern methods and strategies of teaching and learning improves the educational effects, gives students a chance to understand the courses on it and adopt the most suitable way. The teacher's role in modern teaching has greatly changed. He has become a manager, facilitator, coordinator and seeks to enable his students to become active participants of the teaching process and its 
designed phases. The purpose of the various project activities in Bosnia and Herzegovina, especially in the Zenica-Doboj Canton realized by the Pedagogical Institute of Zenica in cooperation with various NGOs is to prepare elementary and secondary school teachers for the application of methods and strategies which are aimed at developing critical thinking among students of all ages and in different school subjects. Critical thinking is one of the most important human skills needed for life in an open and democratic society. Teaching of critical thinking is not an easy task and it cannot be achieved at a certain level of education. It follows the school vertically and depends on a number of conditions such as learning environment, style and competence of teachers, expectations and abilities of students, teaching and learning strategies, school vision, etc.

\section{ERR framework system for learning and teaching}

If we want students to manage information in a quality manner, it is necessary to provide them with a number of skills that will enable them to effectively classify the information and create a meaningful collection of ideas that will ensure practical action. They have to become people who think and learn critically. They must go through the systematic process of critical analysis and reflection, a process that offers them information while they are attending school and serves as a framework system for later critical thinking and reflection. (Steele, Meredith, Temple, 2006:7) Teachers must prepare an effective framework system for thinking and learning that is also clear and systematic. ERR framework system is a process that includes evocation $(\mathbf{E})$, realisation of meaning $(\mathbf{R z})$ and reflection $(\mathbf{R})$ It is the conceptual basis for teaching that is systematically implemented in teaching of all grades and subjects. The system is a way of thinking and teaching that enhances students' critical analysis, giving meaning and critical reflection. (Ibid, 2006:7) When students apply the framework system on their own thinking and self-learning process, they are able to determine the context of their knowledge by adding information to the one they already possess. Information can be actively involved in new experiences or be reflected on the new experiences or they can think about changes of their knowledge.

ERR framework system of teaching consists of three phases and it is a good model of the best way people learn. The model describes the process of thinking in which students are included before the process of learning, during the process and after the learning process. The first phase of ERR framework system is evocation (E). At this stage students are encouraged to use their knowledge and experience on a particular subject and to anticipate and determine the purpose of teaching and learning. This phase connects the previously acquired knowledge with knowledge that is being acquired. This enables the transfer of knowledge. The second phase is the phase of realisation of meaning (Rz) which gets the students through a new text analysis, thematic presentations or other form of presentation and new contents. Students are expected to experience new content and integrate it into their own knowledge. At this stage information is acquired. In the phase of reflection (R) students think about what they have learned in the context of their existing knowledge, rearrange the existing knowledge, build and create a link between the 
existing and new knowledge and create a new quality. In order to develop a practical understanding of the framework system for teaching and learning, this system must be tested in the context of teaching as part of guided instruction and each teaching unit passes through the aforementioned phases of the framework of the system. (Ibid, 2006:8)

Estimated system for teaching and learning allows teacher to:

1. Organize instruction

2. Identify purpose and objectives of teaching

3. Plan additional activities

4. Involve students in purposeful learning

5. Establish a correlation between the subjects

6. Watch the needs and interests of students

With this approach to teaching and learning students' motivation is encouraged. The active problem solving approach to learning contributes to the development of critical thinking, work habits and needs to learn, which are the basis of individual growth and development of each individual. Critical thinking is a higher level of cognitive processing to problem solving, cognitive monitoring and it represents the basis of productive thinking that is necessary in both professional and everyday life of the modern man. (Nikčević-Milković 2004:48) If we talk about critical thinking, solving a problem or learning a new curriculum, students must take an active role in the learning process.

This means that they should invoke a lot of active thinking process, such as active listening, identifying and formulating questions, organizing their thoughts, record the similarities and differences, induction and deduction, the differentiation between valid and invalid conclusions, etc. ERR framework system has special effects combined with cooperative (collaborative) learning.

\section{Cooperative (collaborative) learning}

Cooperative (collaborative) learning is easy to define. Johnson and others (1994) define cooperative learning as teaching in small groups that allow students to work together to achieve maximum success of each individual member of the group. Cooperative learning is learning among students that work together in groups with encouraging of positive interdependence where positive interdependence is developed so as to foster individual responsibility for their own learning and active participation in solving problems. Hundreds of studies have confirmed that, in relation to the individual, cooperative learning shows significantly better results, regardless of the learning subject or age of students. Students are responsible for their own learning and the learning of others. The success of a group member helps the others to be successful. Cooperative teams achieve higher levels of thought and retain information longer than those working individually. Shared learning gives students the opportunity to participate in the discussion, take responsibility for their own learning and exchange ideas, which is useful to increase interest among the 
participants. It also enhances critical thinking. Developing and practicing skills of critical thinking, reasoning and conclusions are important segments of the fundamental starting point of the reformed elementary school. Cooperation functions best within pairs or small groups. The interaction and cooperation between group members make students responsible for learning, and contribute to individual and group success. (Steele, Meredith, Temple, 2006:11)

The advantages of cooperative (collaborative) learning are reflected in the following:

- a higher level of achievement and continued memory

- often a higher-order thinking, deeper understanding and critical thinking

- more focus on the task and more discipline

- greater motivation to achieve results and internal motivation for learning

- greater ability to observe the situation from others' perspectives

- positive, tolerant and supportive relationships with peers regardless of ethnic, racial, religious or gender characteristics, ability and social status, greater social support

- better psychological health, compliance and satisfaction

- positive sense of self-confidence and self-respect

- greater social competence

- more positive attitudes toward school subjects, learning and school

- positive attitude towards teachers, school principals and other school staff

Classrooms and classes involved in cooperative learning are different. Classes are interactive, flexible, lively and often take an active role in process: learningteaching. Collaborative learning is the active learning process that fosters academic and social skills through direct interaction between students, individual accountability and positive interdependence. It is very different from the other group structure, competition or individual for example. (Jensen,2003:235) Cooperative (collaborative) learning is useful when we introduce a complex skill or material that contains more than one correct answer. Positive effects of collaborative learning in the reformed school include: better student success, individual students program, improved social skills, acceptance of peers, increased self-esteem and greater responsibility. 


\section{Elements for successful implementation of cooperative learning}

Cooperative (collaborative) learning is more than group work. The necessary elements for successful implementation of cooperative learning by Jensen (2003) are:

1. Positive interdependence

2. Direct interaction

3. Individual responsibility

4. Collaborative skills and

5. Group processing

Positive interdependence means that the group's success depends on the success of all its members. People need to depend on each other to succeed. One strategy that contributes to mutual dependencies is realized by giving the problematic task that needs to be addressed with minimal resources or materials. In the groups of positive interdependence each student has a dual responsibility. Each student should be given to master the subject matter and they should try to help all other group members to cope with the material. In addition, each student must be aware of the positive interdependence and must consciously strive to coordinate its work with the work of other group members. (Graves, 1997:9)

Direct interaction or interaction "face to face" is cooperation learning where students encourage each other in successful coping with the set task. The students are required to give tasks to interact with other students. This direct communication is very important, it leads to an exchange of ideas, students are encouraged. They help, support, reward or deny each other with arguments.

The successful operation of any group of students and individual responsibility are assessed with a score to know how he/she and other members of the group performed. The best way to facilitate learning responsibility is to give students the roles and responsibilities within the group. (Jensen, 2003:236) Successful execution of the tasks of each group member contributes to the success of the group as a whole. The student who does not contribute to the group work does not share the overall success of the group with the other members.

Collaborative skills that are selected for the teaching depend on the age of pupils. Some of them are nice behaviour, use of magic words (welcome, thank you, excuse me) in all situations, sharing feelings devices, giving and receiving different various opinions, evaluation of oneself and the others, leadership, communication, decision making, confidence building and conflict resolution through non-violent communication. Possession or the adoption of appropriate social communication skills is a prerequisite for the successful work of small groups. (Graves, 1997:10)

Group processing and analysis of group work is an art of understanding and a real learning experience. It consists of a discussion about how the group functions when working together, how successful the group was in relation to the set objectives. This method of analysis should be a regular, integral part of the group 
work because it is possible to complete conscious efforts only if we can improve the functioning of the group.

Eric Jensen (2003) gives a simple plan for the success of cooperative learning, which has ten steps:

1. Content - set clear goals of the unit, create an atmosphere of expectation

2. Explaining task - exactly tell groups how to do a specific task, give specific instruction to express expectation

3. One moment - let students think about the task, so you can anticipate challenges and problems

4. Focus on collaboration - describe the social skills to learn or to substantiate the lesson

5. Begin group work - run things with minimal intervention on your part. Give positive encouragement.

6. Group drafts declaration statements about how group process can improve the school and social skills

7. Students share academic and social skills in conversation and interaction with others - students share their own experiences about how they felt and what they learned

8. The teacher shares academic and cooperative learning observation with students to indicate what was seen, heard and felt. He informs the students about their work and their acting in the course of solving problems.

9. Concluding discussion and the end - teacher asks students about some of the thoughts and responds in the group process and examines individual responsibility in groups.

10. Congratulate the students - clap your hands.

\section{Types of cooperative learning}

There are many types of cooperative (collaborative) learning that can be described through a kind of cooperative (collaborative) group. A cooperative (collaborative) group or team are different from ordinary working groups. A working group will become collaborative (team) if the focus action of group members is directed towards the goal and group members must collaborate to this end. Types of cooperative groups by Graves (1997) are as follows:

1. Formal cooperative group

2. Student teams

3. Puzzle-groups

4. Informal cooperative groups

Formal cooperative groups are heterogeneous groups composed of three students. The students within formal groups differ in ability, gender, ethnicity, etc. These groups include five characteristics of cooperative learning by Jensen (2003). 
These groups are used for several lectures. Working in small heterogeneous groups is the best way to acquire new knowledge. Groups should not be too heterogeneous since large differences among students can lead to certain steps in the process of thinking and development failures. (Vilotijević, 2007:47). Among the tasks that we give these groups are mostly problem-solving and decision making, homework review, performing of laboratory exercises, lectures, etc. This type of creative group is particularly successful at mastering the skills needed to solve problems, develop creativity and critical thinking. (Graves, 1997:11) The final stage of this type of cooperative learning is the exchange of experiences at the level of large groups (classes). The whole class is included in the discussion about how each group worked individually and how the students performed their individual tasks within small groups.

Student teams or STAD groups (Student Team Achievement Division) are the most widely used variant of cooperative learning. This group consists of four students with different abilities who work together. This approach to group formation is favourable for overcoming clear goals that result in an accurate answer. It is especially suitable for teaching math, grammar, geography, foreign language. Working in STAD groups is adapted to cope with elemental content and skills as opposed to the formal heterogeneous group in which the work is adapted to cope with more complex material. Teams function well for about six to eight weeks. One or two weeks are needed to learn how to work in a team, and then, in the last week, members are often willing to create new teams. (Jensen, 2003:238) Students' teams can work on projects. Working on projects as a form of cooperative learning enables solidarity action and transferred competence to act and creates a sense of self-worth. It can prepare students for the demands placed before them by the professional life. The project is less suitable for training and determination, revision and control of learning. (Meyer, 2002:175)

Puzzle-groups (puzzle) as a form of cooperative learning were developed by Aronson (Aronson \& Pantoe, 1997). STAD group, puzzle-group apply stylized approach. A class department of 30 students is divided into 5 heterogeneous groups of 6 students and all groups work on the same material that the teacher has divided so that each group member works on a single segment. Puzzle groups, of course, can be used only for the material that can be divided into several segments. Except for this restriction, puzzle groups can be broadly applied. (Graves, 1997:12) The structures of the puzzle for cooperative learning are characterized by the fact that each member of the group for cooperative learning (home group) becomes an expert (expert) for various aspects of the topics we are studying. For example, if a group study is based on "human body" one member could become an expert for the "heart and blood vessels", one for "sensory system organs", the third for "system of the respiratory organs", the fourth for the "extraction organs system", etc. After individual work on a particular segment of the study materials, all students within the home group engaged in the same segment come together and form an expert group. The expert groups improve what they have learned up to that time. After that the experts return to the home group and expose the other members what they learned in expert groups. Students learn from each other about the contents of 
different segments, the increased interest and motivation to listen to the presentation. The task of the experts is not only to expose what they have learned. They should also ask and answer questions of other group members, to be sure that they have learned each piece of text. (Steele, Meredith, Temple, 2006:23)

\begin{tabular}{|c|c|c|}
\hline Evocation (E) & Realisation of meaning (RZ) & Reflection (R) \\
\hline BRAINSTORMING & INSERT-TABLE & BINGO \\
\hline $\begin{array}{l}\text { CONTRACT AND } \\
\text { EXCHANGE }\end{array}$ & T-TABLE & INSERT-TABLE \\
\hline BINGO & MINI LESSON & $\begin{array}{l}\text { CONTRACT AND } \\
\text { EXCHANGE }\end{array}$ \\
\hline T-TABLE & VENN'S DIAGRAM & T-TABLE \\
\hline TOUR GALLERY & DOUBLE NEWS & TOUR GALLERY \\
\hline GRAPE & RIGID CLASSES & GRAPE \\
\hline FREE WRITING & RECIPROCAL TEACH & CUBE GAME \\
\hline CUBE GAME & PUZZLE I & JOINT DISCUSSION \\
\hline PREDICTION OF THE PAIR & PUZZLE II & DEBATE \\
\hline TANK DISCUSSION & $\begin{array}{l}\text { READING AND } \\
\text { SUMMARIZING IN PAIRS }\end{array}$ & THE CIRCLE WITHIN \\
\hline KWL-TABLE & SECURITY AXIS & KWL-TABLE \\
\hline DEBATE & TANK READING & FREE WRITING \\
\hline THE CIRCLE WITHIN & LITERARY CORNER & VENN'S DIAGRAM \\
\hline
\end{tabular}

Table 1: Strategies of cooperative learning in the ERR framework system

Informal cooperative groups work in pairs during one hour and students learn more about a specific teaching unit. The general plan consists in the fact that the teacher structures the lecture so that it focuses on a number of central questions and a few short segments. This approach gives students the opportunity to prepare for the presentation and to deal with contents during the lectures to formulate some sort of conclusion. Phases in the use of informal cooperative groups are as follows:

1. Prepare approximately 6 questions and give them to couples before the lecture. Pupils have 5 minutes to talk about what they know about the given topic and they form the structure of lectures.

2. Present the first part of lecture within 5-10 minutes. Afterwards students discuss 2-3 minutes the exposed segment of the treated material. It is possible to give answers to questions 1 or 2 in which this segment can be answered.

3. Expose other segments of lectures, limiting them in time given in the first segment. After each segment students discuss in pairs the presented material.

4. At the end couples discuss 5-6 minutes about the lecture, identifying key answers and summarizing.

Different sorts of cooperative learning strategies can be easily incorporated into lessons and applied to all courses and students can provide opportunities for 
cooperative work in all phases of the ERR framework system. It is essential that all teachers incorporate cooperative learning strategies in the table ERR framework system. Jeannie L. Stele, Kurtis S. Meredith, Charles Temple, in the manual "Reading and writing for critical thinking " (2006.) give a great view of the collaborative (cooperative) strategies that can be used in all phases of teaching. Because of their large number, I will display just a few that can be implemented in upper grades of elementary school.

Teachers and schools have adopted cooperative learning strategies, mostly to break frontal teaching and their achievements in the development of desirable relationships are valued only as an incidental bonus. (Kuzmanović-Buljubašić, 2009:51) In order to create interaction in the classroom, it is necessary to overcome the established roles that both teachers and students have had. The teacher has always been in the middle as the lecturer, applying mostly frontal teaching methods and the student has always been largely responsible for memorizing and reproduction of the content. We cannot dispute the efficiency of certain traditional teaching, but it is essential that we understand its limited scope. (Suzić, 2001:28) Cooperative learning, team work and collaborative groups are one of the most important activities that will be required in the future and will be crucial to the success of each individual in the $21^{\text {st }}$ century.

\section{Research Methodology}

\section{The subject of research}

The subject of this research relates to the application of ERR framework system and cooperative learning strategies in subject teaching of elementary school upper grades.

\section{The objective of the research}

The main objective is to investigate and determine whether the attitudes of students in elementary school upper grades are positive or negative when it comes to the introduction of modern teaching and learning strategies such as the ERR framework system and cooperative learning that are set in the Program "Reading and Writing for Critical Thinking".

\section{The aims of the research}

The following aims of research derive from the objective set above:

To examine the role and importance of ERR framework system and strategies of cooperative learning in the process of acquiring knowledge, skills and habits of students in elementary school upper grades.

To examine to what extent of ERR framework system and cooperative learning strategies contribute to the critical thinking development of students in elementary school upper grades. 
To examine in which subjects is the application of ERR framework system and cooperative learning strategies most common.

\section{Research Methods}

In the research of this paper work we used these methods: theoretical analysis, descriptive-analytical methods and survey method. The data obtained by the study are presented in tables and graphs, and were processed by statistical methods of data processing using the program package SPSS for Windows 16.00.

\section{Research Instruments}

During the research it was necessary to create an instrument that would measure attitudes of students in elementary school upper grades on the role and importance of ERR framework systems and cooperative learning strategies. For this purpose we made a scale of assessment for students (SPU) which is a model of Likert three-level scale type $(1=$ no, $2=$ somewhat, $3=$ yes $)$. A scale of assessments for students is based on the hierarchy of needs by H. Murray (1938) and includes the following constructs:

- power and self-control

- achievements

- belonging and love

Four items (claims) are given for each construct and the maximum score for each construct is 12 .

\section{Research hypotheses}

$\mathbf{H}_{1}$ : We assume that the attitudes of students in elementary school upper grades are positive when it comes to the introduction of modern teaching and learning strategies such as the ERR framework system and cooperative learning.

$\mathbf{H}_{2}$ : It is assumed that the implementation of the ERR framework systems and cooperative learning strategies is used to develop critical thinking in students in elementary school upper grades.

$\mathbf{H}_{3}$ : We assume that ERR framework system and strategies of cooperative learning are frequently used in teaching language and literature, subjects related to social sciences. 


\section{The sample of respondents}

Sample included students from $6^{\text {th }}$ to $8^{\text {th }}$ grade (at the school where teachers apply program "Reading and Writing for Critical Thinking" - RWCT). The sample included 5 elementary schools in the Zenica-Doboj Canton: ES "Mak Dizdar" Zenica (M.D.), ES "Meša Selimović" Zenica (M.S.), ES "Rešad Kadić’" Tešanj (R.K.), ES "Musa Ćazim Ćatic" Zenica (M.Ć.Ć.) and ES "Safvet-beg Bašagić" Visoko (S.B.B.).

\begin{tabular}{|c|c|c|c|c|c|c|c|c|c|}
\hline \multirow[t]{2}{*}{ School } & \multicolumn{3}{|c|}{ Number of respondents } & \multirow[t]{2}{*}{ Grade } & \multicolumn{5}{|c|}{$\begin{array}{l}\text { Success in learning (school year: } 2010 / 2011) \\
1^{\text {st }} \text { term }\end{array}$} \\
\hline & M & $\mathrm{F}$ & Whole & & 5 & 4 & 3 & 2 & 1 \\
\hline M.D. & 24 & 26 & 50 & VII/VIII & 18 & 24 & 7 & 1 & 0 \\
\hline M.S. & 26 & 24 & 50 & VIII & 23 & 21 & 5 & 1 & 0 \\
\hline R.K. & 23 & 27 & 50 & VII & 20 & 19 & 8 & 3 & 0 \\
\hline M.Ć.Ć. & 27 & 23 & 50 & VII/VIII & 28 & 10 & 9 & 3 & 0 \\
\hline S.B.B. & 23 & 27 & 50 & VII & 20 & 21 & 8 & 1 & 0 \\
\hline TOTAL & 123 & 127 & 250 & VII/VIII & 109 & 95 & 37 & 9 & $\mathbf{0}$ \\
\hline
\end{tabular}

\section{The research results with discussion}

Table 2: The sample of respondents

The main objective of this study was to examine and determine whether the attitudes of students in upper grades of elementary school are positive or negative when it comes to the introduction of modern learning and teaching strategies such as the ERR framework system and cooperative learning that make part of the programme "Reading and Writing to Critical Thinking". With regard to the subject of teaching, a scale assessment for students (SPU) was constructed through which students presented their views regarding cooperative (cooperative) learning within the framework of "Reading and Writing for Critical Thinking". The scale was constructed to include three constructs:

- the power and self control

- achievements

- belonging and love

These three constructs were taken from the hierarchy of needs by H. Murray (1938), a scale model of a Likert three-level scale type. The data were processed by means of the statistical package SPSS for Windows 16.00. We used the $\mathrm{X}^{2}$ test (chisquare test), which is the approach to testing the null hypothesis in five modalities (five elementary schools) and there was no statistically significant difference in the attitudes of students in upper grades of the teaching with respect to the school from which they come. After the statistical analysis, the following results were:

\section{Claim 1:}

Working in groups, with cooperative (collaborative) learning, 


\begin{tabular}{|c|c|c|c|c|}
\hline \multicolumn{5}{|c|}{ strengthens my communication skills. } \\
\hline SCHOOL & NO & SOMEWHAT & YES & TOTAL \\
\hline M.D. & 2 & 17 & 31 & 50 \\
\hline M.S. & 2 & 19 & 29 & 50 \\
\hline R.K. & 6 & 18 & 26 & 50 \\
\hline M.Ć.Ć. & 1 & 15 & 34 & 50 \\
\hline S.B.B. & 1 & 8 & 41 & 50 \\
\hline TOTAL & $\mathbf{1 2}$ & $\mathbf{7 7}$ & $\mathbf{1 6 1}$ & $\mathbf{2 5 0}$ \\
\hline
\end{tabular}

Table 3

\section{Chi-Square Tests}

\begin{tabular}{|l|c|c|c|}
\hline & Value & df & Asymp. Sig. (2-sided) \\
\hline Pearson Chi-Square & $20,000^{\mathrm{a}}$ & 16 & .220 \\
Likelihood Ratio & 16,094 & 16 & .446 \\
N of Valid Cases & 5 & & \\
\hline
\end{tabular}

a. 25 cells $(100.0 \%)$ expected count less than 5 . The minimum expected count was 20 .

Description: Pearson chi-square is 20.00 and it is not significant because Asymp. Sig.$=0.220$ is much higher than the limit $(0.05)$. There is no statistically significant difference with respect to responses of students from the five schools regarding the statement: Working in groups, with cooperative (collaborative) learning, strengthens my communication skills.

\begin{tabular}{|c|c|c|c|c|}
\hline \multicolumn{5}{|c|}{$\begin{array}{l}\text { Claim 2: } \\
\text { Working in groups, with cooperative (collaborative) learning, allows me to think } \\
\text { critically. }\end{array}$} \\
\hline SCHOOL & NO & SOMEWHAT & YES & TOTAL \\
\hline M.D. & 7 & 33 & 10 & 50 \\
\hline M.S. & 3 & 27 & 20 & 50 \\
\hline R.K. & 4 & 25 & 21 & 50 \\
\hline M.Ć.Ć. & 9 & 17 & 24 & 50 \\
\hline S.B.B. & 9 & 19 & 22 & 50 \\
\hline TOTAL & 32 & 121 & 97 & 250 \\
\hline
\end{tabular}

Table 4 


\section{Chi-Square Tests}

\begin{tabular}{|c|c|c|c|}
\hline & Value & df & Asymp. Sig. (2-sided) \\
\hline Pearson Chi-Square & $15,000^{\mathrm{a}}$ & 12 & .241 \\
Likelihood Ratio & 13,322 & 12 & .346 \\
N of Valid Cases & 5 & & \\
\hline
\end{tabular}

a. 20 cells $(100.0 \%)$ expected count less than 5 . The minimum expected count was 20 .

Description: Pearson chi-square is 15.00 and it is not significant because Asymp. Sig.$=0.241$ is much higher than the limit (0.05). There is no statistically significant difference with respect to responses of students from the five schools regarding the statement: Working in groups, with cooperative (collaborative) learning, allows me to think critically.

\begin{tabular}{|c|c|c|c|c|}
\hline \multicolumn{5}{|c|}{$\begin{array}{l}\text { Claim 3: } \\
\text { The experiences we acquire by working in small groups, with cooperative } \\
\text { (collaborative) learning, are applied in everyday situations. }\end{array}$} \\
\hline SCHOOL & $\mathrm{NO}$ & SOMEWHAT & YES & TOTAL \\
\hline M.D. & 4 & 24 & 22 & 50 \\
\hline M.S. & 4 & 30 & 16 & 50 \\
\hline R.K. & 3 & 27 & 20 & 50 \\
\hline M.Ć.Ć. & 2 & 28 & 20 & 50 \\
\hline S.B.B. & 3 & 15 & 32 & 50 \\
\hline TOTAL & 16 & 124 & 110 & 250 \\
\hline
\end{tabular}

Table 5

\begin{tabular}{|l|c|c|c|}
\hline \multicolumn{1}{|c}{ Chi-Square Tests } \\
\hline & Value & df & $\begin{array}{c}\text { Asymp. Sig. } \\
(2 \text {-sided })\end{array}$ \\
\hline Pearson Chi-Square & $10,000^{\mathrm{a}}$ & 8 & .265 \\
Likelihood Ratio & 10,549 & 8 & .229 \\
N of Valid Cases & 5 & & \\
\hline
\end{tabular}

a. 15 cells (100.0\%) expected count less than 5 . The minimum expected count was 20 .

Description: Pearson chi-square is 10.00 and it is not significant because Asymp. Sig.$=0.265$ is much higher than the limit $(0.05)$. There is no statistically significant difference with respect to responses of students from the five schools regarding the statement: The experiences we acquire by working in small groups, with cooperative (collaborative) learning, are applied in everyday situations. 


\begin{tabular}{|c|c|c|c|c|}
\hline \multicolumn{5}{|c|}{$\begin{array}{l}\text { Claim 4: } \\
\text { Cooperate (collaborative) learning is useful for mastering the problem } \\
\text { tasks and situations. }\end{array}$} \\
\hline SCHOOL & $\mathrm{NO}$ & SOMEWHAT & YES & TOTAL \\
\hline M.D. & 1 & 6 & 43 & 50 \\
\hline M.S. & 3 & 9 & 38 & 50 \\
\hline R.K. & 3 & 10 & 37 & 50 \\
\hline M.Ć.Ć. & 1 & 10 & 39 & 50 \\
\hline S.B.B. & 0 & 10 & 40 & 50 \\
\hline TOTAL & 8 & 45 & 197 & 250 \\
\hline
\end{tabular}

Table 6

Chi-Square Tests

\begin{tabular}{|c|c|c|c|}
\hline & Value & df & $\begin{array}{c}\text { Asymp. Sig. } \\
\text { (2-sided) }\end{array}$ \\
\hline Pearson Chi-Square & $15,000^{\mathrm{a}}$ & 12 & .241 \\
Likelihood Ratio & 13,322 & 12 & .346 \\
N of Valid Cases & 5 & & \\
\hline
\end{tabular}

a. 20 cells $(100.0 \%)$ expected count less than 5 . The minimum expected count was 20 .

Description: Pearson chi-square is 15.00 and it is not significant because Asymp. Sig. $=0.241$ is much higher than the limit $(0.05)$. There is no statistically significant difference with respect to responses of students from the five schools regarding the statement: Cooperative (collaborative) learning is useful for mastering the problem tasks and situations.

\begin{tabular}{|c|c|c|c|c|}
\hline \multicolumn{5}{|c|}{$\begin{array}{l}\text { Claim 5: } \\
\text { In my school cooperative (collaborative) learning is present in language } \\
\text { classes and literature and social sciences (history, geography). }\end{array}$} \\
\hline SCHOOL & NO & SOMEWHAT & YES & TOTAL \\
\hline M.D. & 1 & 12 & 37 & 50 \\
\hline M.S. & 2 & 9 & 39 & 50 \\
\hline R.K. & 3 & 13 & 34 & 50 \\
\hline M.Ć.Ć. & 3 & 17 & 30 & 50 \\
\hline S.B.B. & 2 & 13 & 35 & 50 \\
\hline TOTAL & 11 & 64 & 175 & 250 \\
\hline
\end{tabular}

Table 7 
Chi-Square Tests

\begin{tabular}{|l|c|c|c|}
\hline & Value & df & $\begin{array}{c}\text { Asymp. Sig. } \\
(2 \text {-sided })\end{array}$ \\
\hline Pearson Chi-Square & $10,000^{\mathrm{a}}$ & 8 & .265 \\
Likelihood Ratio & 9,503 & 8 & .302 \\
N of Valid Cases & 5 & & \\
\hline
\end{tabular}

a. 15 cells $(100,0 \%)$ expected count less than 5 . The minimum expected count was .20.

Description: Pearson chi-square is 10.00 and it's not significant because Asymp. Sig.$=0.265$ is much higher than the limit $(0.05)$. There is no statistically significant difference with respect to responses of students from the five schools regarding the statement: In my school cooperative (collaborative) learning is present in language classes and literature and social sciences (history, geography).

\begin{tabular}{|c|c|c|c|c|}
\hline \multicolumn{5}{|c|}{$\begin{array}{l}\text { Claim 6: } \\
\text { In my school cooperative (collaborative) learning is present in class for } \\
\text { natural sciences (mathematics, physics, biology, chemistry). }\end{array}$} \\
\hline SCHOOL & $\mathrm{NO}$ & SOMEWHAT & YES & TOTAL \\
\hline M.D. & 10 & 34 & 6 & 50 \\
\hline M.S. & 43 & 7 & 0 & 50 \\
\hline R.K. & 15 & 15 & 20 & 50 \\
\hline M.Ć.Ć. & 13 & 34 & 3 & 50 \\
\hline S.B.B. & 26 & 28 & 6 & 50 \\
\hline TOTAL & 107 & 118 & 35 & 250 \\
\hline
\end{tabular}

Table 8

\begin{tabular}{|c|c|c|c|}
\hline & Chi-Square Tests \\
& Value & df & Asymp. Sig. (2-sided) \\
\hline Pearson Chi-Square & $15,000^{\mathrm{a}}$ & 12 & .241 \\
Likelihood Ratio & 13,322 & 12 & .346 \\
N of Valid Cases & 5 & & \\
\hline
\end{tabular}

a. 20 cells $(100.0 \%)$ expected count less than 5 . The minimum expected count was 20 .

Description: Pearson chi-square is 15.00 and it is not significant because Asymp. Sig.$=0.241$ is much higher than the limit $(0.05)$. There is no statistically significant difference with respect to responses of students from the five schools regarding the statement: 
In my school cooperative (collaborative) learning is present in class for natural sciences (mathematics, physics, biology, chemistry).

\begin{tabular}{|c|c|c|c|c|}
\hline \multicolumn{5}{|c|}{$\begin{array}{l}\text { Claim7: } \\
\text { In my school cooperative (collaborative) learning is present in classes } \\
\text { teaching music, art and technical subjects and classes teaching physical } \\
\text { and health education. }\end{array}$} \\
\hline SCHOOL & $\mathrm{NO}$ & SOMEWHAT & YES & TOTAL \\
\hline M.D. & 22 & 18 & 10 & 50 \\
\hline M.S. & 11 & 39 & 0 & 50 \\
\hline R.K. & 12 & 17 & 21 & 50 \\
\hline M.Ć.Ć. & 24 & 15 & 6 & 50 \\
\hline S.B.B. & 12 & 25 & 13 & 50 \\
\hline TOTAL & 81 & 114 & $\mathbf{5 0}$ & 250 \\
\hline
\end{tabular}

Table 9

Chi-Square Tests

\begin{tabular}{|l|c|c|c|}
\hline & Value & df & $\begin{array}{c}\text { Asymp. Sig. } \\
(2 \text {-sided })\end{array}$ \\
\hline Pearson Chi-Square & $20,000^{\mathrm{a}}$ & 16 & .220 \\
Likelihood Ratio & 16,094 & 16 & .446 \\
N of Valid Cases & 5 & & \\
\hline
\end{tabular}

a. 25 cells (100.0\%) expected count less than 5 . The minimum expected count was 20 .

Description: Pearson chi-square is 20.00 and it is not significant because Asymp. Sig.$=0.220$ is much higher than the limit $(0.05)$. There is no statistically significant difference with respect to responses of students from the five schools regarding the statement: In my school cooperative (collaborative) learning is present in class teaching music, art and technical subjects and classes teaching physical and health education. 


\begin{tabular}{|c|c|c|c|c|}
\hline \multicolumn{5}{|c|}{$\begin{array}{l}\text { Claim 8: } \\
\text { Students are more active if teachers use class work in small groups with } \\
\text { cooperative (collaborative) learning. }\end{array}$} \\
\hline SCHOOL & NO & SOMEWHAT & YES & TOTAL \\
\hline M.D. & 2 & 21 & 27 & 50 \\
\hline M.S. & 2 & 29 & 19 & 50 \\
\hline R.K. & 6 & 17 & 27 & 50 \\
\hline M.Ć.Ć. & 4 & 18 & 28 & 50 \\
\hline S.B.B. & 2 & 8 & 40 & 50 \\
\hline TOTAL & 16 & 93 & 141 & 250 \\
\hline
\end{tabular}

Table 10

Chi-Square Tests

\begin{tabular}{|l|c|c|c|}
\hline & Value & $\mathrm{df}$ & $\begin{array}{c}\text { Asymp. Sig. } \\
\text { (2-sided) }\end{array}$ \\
\hline Pearson Chi-Square & $10,000^{\mathrm{a}}$ & 8 & .265 \\
Likelihood Ratio & 9,503 & 8 & .302 \\
N of Valid Cases & 5 & & \\
\hline
\end{tabular}

a. 15 cells $(100.0 \%)$ expected count less than 5 . The minimum expected count was .20 .

Description: Pearson chi-square is 10.00 and it is not significant because Asymp. Sig.$=0.265$ is much higher than the limit $(0.05)$. There is no statistically significant difference with respect to responses of students from the five schools regarding the statement: Students are more active if teachers use class work in small groups with cooperative (collaborative) learning.

\begin{tabular}{|c|c|c|c|c|}
\hline \multicolumn{5}{|c|}{$\begin{array}{l}\text { Claim 9: } \\
\text { I prefer to learn in a group, together with my peers, rather than } \\
\text { independently through individual work. }\end{array}$} \\
\hline SCHOOL & $\mathrm{NO}$ & SOMEWHAT & YES & TOTAL \\
\hline M.D. & 7 & 11 & 32 & 50 \\
\hline M.S. & 8 & 16 & 26 & 50 \\
\hline R.K. & 9 & 17 & 24 & 50 \\
\hline M.Ć.Ć. & 13 & 12 & 25 & 50 \\
\hline S.B.B. & 5 & 10 & 35 & 50 \\
\hline TOTAL & 42 & 66 & 142 & 250 \\
\hline
\end{tabular}

Table 11 


\section{Chi-Square Tests}

\begin{tabular}{|l|c|c|c|}
\hline & Value & df & $\begin{array}{c}\text { Asymp. Sig. } \\
\text { (2-sided) }\end{array}$ \\
\hline Pearson Chi-Square & $15,000^{\mathrm{a}}$ & 12 & .241 \\
Likelihood Ratio & 13,322 & 12 & .346 \\
N of Valid Cases & 5 & & \\
\hline
\end{tabular}

a. 20 cells $(100.0 \%)$ expected count less than 5 . The minimum expected count was .20.

Description: Pearson chi-square is 15.00 and it is not significant because Asymp. Sig.$=0.241$ is much higher than the limit $(0.05)$. There is no statistically significant difference with respect to responses of students from the five schools regarding the statement: I prefer to learn in a group, together with my peers, rather than independently through individual work.

\begin{tabular}{|c|c|c|c|c|}
\hline \multicolumn{5}{|c|}{$\begin{array}{l}\text { Claim 10: } \\
\text { I look forward to teachers organizing classes working in small groups. }\end{array}$} \\
\hline SCHOOL & NO & SOMEWHAT & YES & TOTAL \\
\hline M.D. & 3 & 10 & 37 & 50 \\
\hline M.S. & 2 & 12 & 36 & 50 \\
\hline R.K. & 4 & 19 & 27 & 50 \\
\hline M.Ć.Ć. & 1 & 15 & 34 & 50 \\
\hline S.B.B. & 3 & 4 & 42 & 50 \\
\hline TOTAL & 13 & 60 & 176 & 250 \\
\hline
\end{tabular}

Table 12

\section{Chi-Square Tests}

\begin{tabular}{|l|c|c|c|}
\hline & Value & df & $\begin{array}{c}\text { Asymp. Sig. } \\
\text { (2-sided) }\end{array}$ \\
\hline Pearson Chi-Square & $10,000^{\mathrm{a}}$ & 8 & .265 \\
Likelihood Ratio & 9,503 & 8 & .302 \\
N of Valid Cases & 5 & & \\
\hline
\end{tabular}

a. 15 cells $(100.0 \%)$ expected count less than 5 . The minimum expected count was 20 .

Description: Pearson chi-square is 10.00 and it's not significant because Asymp. Sig.$=0.265$ is much higher than the limit $(0.05)$. There is no statistically significant difference with respect to responses of students from the five schools regarding the statement: I look forward to teachers organizing classes by working in small groups. 


\begin{tabular}{|c|c|c|c|c|}
\hline \multicolumn{5}{|c|}{$\begin{array}{l}\text { Claim 11: } \\
\text { Classes are more interesting when teachers apply modern methods of learning and } \\
\text { teaching. }\end{array}$} \\
\hline SCHOOL & $\mathrm{NO}$ & SOMEWHAT & YES & TOTAL \\
\hline M.D. & 1 & 12 & 37 & 50 \\
\hline M.S. & 1 & 8 & 41 & 50 \\
\hline R.K. & 2 & 20 & 28 & 50 \\
\hline M.Ć.Ć. & 0 & 17 & 33 & 50 \\
\hline S.B.B. & 1 & 8 & 41 & 50 \\
\hline TOTAL & 5 & 65 & 180 & 250 \\
\hline
\end{tabular}

Table 13

Chi-Square Tests

\begin{tabular}{|l|c|c|c|}
\hline & Value & df & $\begin{array}{c}\text { Asymp. Sig. } \\
\text { (2-sided) }\end{array}$ \\
\hline Pearson Chi-Square & $20,000^{\mathrm{a}}$ & 16 & .220 \\
Likelihood Ratio & 16,094 & 16 & .446 \\
N of Valid Cases & 5 & & \\
\hline
\end{tabular}

a. 25 cells $(100.0 \%)$ expected count less than 5 . The minimum expected count was .20 .

Description: Pearson chi-square is 20.00 and it is not significant because Asymp. Sig.$=0.220$ is much higher than the limit $(0.05)$. There is no statistically significant difference with respect to responses of students from the five schools regarding the statement: Classes are more interesting when teachers apply modern methods of learning and teaching.

\section{Claim 12:}

In our school teachers respect the interests, needs and ideas of their students.

\begin{tabular}{|c|c|c|c|c|}
\hline SCHOOL & NO & SOMEWHAT & YES & TOTAL \\
\hline M.D. & 0 & 27 & 23 & 50 \\
\hline M.S. & 4 & 37 & 9 & 50 \\
\hline R.K. & 3 & 20 & 27 & 50 \\
\hline M.Ć.Ć. & 2 & 23 & 25 & 50 \\
\hline S.B.B. & 2 & 11 & 37 & 50 \\
\hline TOTAL & $\mathbf{1 1}$ & $\mathbf{1 1 8}$ & $\mathbf{1 2 1}$ & $\mathbf{2 5 0}$ \\
\hline
\end{tabular}

Table 14 
Chi-Square Tests

\begin{tabular}{|l|c|c|c|}
\hline & Value & df & $\begin{array}{c}\text { Asymp. Sig. } \\
\text { (2-sided) }\end{array}$ \\
\hline Pearson Chi-Square & $15,000^{\mathrm{a}}$ & 12 & .241 \\
Likelihood Ratio & 13,322 & 12 & .346 \\
N of Valid Cases & 5 & & \\
\hline
\end{tabular}

a. 20 cells $(100.0 \%)$ expected count less than 5 .

The minimum expected count was .20 .

Description: Pearson chi-square is 15.00 and it's not significant because Asymp. Sig.$=0.241$ is much higher than the limit $(0.05)$. There is no statistically significant difference with respect to responses of students from the five schools regarding the statement: In our school teachers respect the interests, needs and ideas of their students.

\section{Conclusion}

The results of the research show that positive attitudes of students are predominant if we talk about the role and importance of ERR framework system and strategies of cooperative learning in the teaching process in upper grades of the elementary school. Through data processing it was observed that there was no statistically significant difference in the responses and attitudes of students when it came to the role and importance of the ERR framework system and cooperative learning strategies in developing critical thinking. 97 respondents (39\%) believed that the ERR framework system contributed to the development of critical thinking, 121 respondents $(48.4 \%)$ opted for the option "somewhat", and 32 respondents (12.8\%) for the option "no" on the scale. Students-respondents in the sample were well aware of the importance of cooperative learning strategies in teaching and their application in solving problem situations and use in everyday life. 110 respondents (44\%) believed that the experience gained through collaborative learning was applicable in everyday situations, and 197 respondents (79\%) considered it useful for resolving problem situations and tasks. If we talk about the presence of ERR framework system and strategies of cooperative learning in the teaching of school subjects, the third hypothesis was confirmed, namely that the cooperative learning and ERR framework system were most common in language teaching and literature and social sciences. 175 respondents $(70 \%)$ gave answers that supported this hypothesis. 118 subjects (47\%) believed that the ERR framework system and cooperative learning were to some extent applied in the teaching of natural sciences, and $114(45.6 \%)$ that cooperative learning was somewhat applied in the teaching of music, art, technical education and physical and health education. It was observed that students preferred classes that are organized with the use of cooperative learning. The peer education program "Reading and Writing for Critical Thinking" was considered very important. The application of modern learning and teaching 
strategies in teaching, respecting the interests and needs of students, will strengthen the competencies required for every individual for the challenges of the $21^{\text {st }}$ century. The reform of school education in Bosnia and Herzegovina is understood as "the school on human scale" which is directly related to the recognition of multiple learning styles, development of critical thinking in students. The programme "Reading and Writing for Critical Thinking" (RWCT) works in favour of these (new) challenges, establishing a reformed elementary school.

\section{Bibliography}

1. Graves, B. (1997).Cooperative learning. Didactic Guideposts No.7.Zenica: Pedagogical Institute and the Pedagogical Academy in Zenica

2. Jensen, E. (2003).SUPER TEACHING-Teaching strategies for quality education and successful learning.Zagreb:Educa

3. Kuzmanovic Buljubašić,V. (2009).Cooperative learning as an indicator of the quality of education. Life and school No.21, p.50-57 Osijek: Faculty of Philosophy, Faculty of Teacher

4. Meyer, H. (2002). Teaching catch-class discussion of didactics, teaching methods and school development.Zagreb: Educa

5. Nikčević-Milke, A. (2004).Active learning in the higher education level.Life and School No.12, p.47-54.Osijek: Faculty of Philosophy, Faculty of Teacher

6. Steele, J., Meredith, K., Temple, C. (2006).Cooperative learning and instructional planning and evaluation unit. Sarajevo: COI Step by step

7. Steele, J., Meredith, K., Temple, C. (2006).The framework system of critical thinking in the overall curriculum and methods for improving critical thinking. Sarajevo: COI Step by step

8. Suzić, N. (2001).Interaction as a form of learning and teaching.Educational technology No.3-4, p.27-48.New York: Center for Management in Education

9. Terhart, E. (2001).Methods of teaching and learning.Zagreb: Educa

10. Vilotijevic, N. (2007). Associate cooperative teaching.Educational Technology No.1-2, p.44-63. New York: Center for Management in Education 
Metodički obzori 7(2012)1

Original research paper

UDK: 371.311.4:159.95

Received: 23. 11. 2010.

ERR OKVIRNI SISTEM I KOOPERATIVNO UČENJE

mr. sc. Fehim Terzić

Stručni savjetnik za oblast obrazovanja

Pedagoški zavod Zeničko-dobojskog kantona

Bosna i Hercegovina

e-mail: fehimterzic@gmail.com

\section{Sažetak}

Program obuke "Čitanjem i pisanjem do kritičkog mišljenja" (RWCT) predstavlja sveobuhvatni pristup i uvođenje nove metodologije koja promovira aktivno, samostalno učenje i kritičko mišljenje. Metode RWCT-a uključuju strategije istraživanja, kreativnog mišljenja, kooperativnog učenja, diskusije i rasprave, te pisanje kao sredstvo ličnog izražavanja i pomoć u učenju. U Bosni i Hercegovini navedenu obuku provodi COI Step by step iz Sarajeva, a istu pohađaju i nastavnici sa područja Zeničko-dobojskog kantona. Bazična obuka ima za cilj razvijanje kompetencija nastavnika za primjenu ERR okvirnog sistema i različitih vidova kooperativnog učenja kao suvremenih strategija koje doprinose razvoju kritičkog mišljenja kod učenika. U okviru ovog rada cilj je ispitati da li su stavovi učenika viših razreda osnovne škole pozitivni ili negativni kada je u pitanju uloga i značaj ERR okvirnog sistema i kooperativnog učenja u procesu stjecanja znanja. U istraživanju su korištene sljedeće metode: metoda teorijske analize, deskriptivno-analitička metoda i Servej metoda, a od instrumenata specijalno dizajnirana Skala procjene za učenike (SPU). Rezultati istraživanja idu u prilog afirmaciji suvremenih strategija učenja i podučavanja kao što su ERR okvirni sistem i kooperativno učenje jer doprinose kognitivnom, konativnom i afektivnom razvoju učenika i jačanju njihovih kompetencija za XXI stoljeće.

Ključne riječi: ERR okvirni sistem, kooperativno učenje, kooperativne grupe, kritičko mišljenje, evokacija, razumijevanje značenja, refleksija, podučavanje 